\title{
EFEKTIVITAS MODEL PEMBELAJARAN TUTOR SEBAYA DENGAN PENGGUNAAN LKS TERHADAP HASIL BELAJAR SISWA DALAM MENYELESAIKAN SOAL CERITA PADA MATERI KELILING DAN LUAS LINGKARAN
}

\author{
Ariestha Widyastuty Bustan ${ }^{1}$, Hasan Samsi ${ }^{2}$, Mustafa A. H Ruhama ${ }^{3}$ \\ ${ }^{1}$ Program Studi Matematika, Universitas Pasifik Morotai \\ Jalan Desa Darame, Kecamatan Morotai Selatan, Kabupaten Pulau Morotai, Maluku Utara, Indonesia \\ ${ }^{2.3}$ Program Studi Pendidikan Matematika, Universitas Khairun Ternate \\ Jalan Bandara Babullah, Kecamatan Ternate Utara, Kota Ternate, Maluku Utara, Indonesia \\ e-mail: ${ }^{1}$ ariesthawidyastutybustan@gmail.com
}

\begin{abstract}
Abstrak
Penelitian ini merupakan penelitian eksperimen yang bertujuan mengetahui efektivitas model pembelajaran tutor sebaya dengan penggunaan LKS terhadap hasil belajar siswa dalam menyelesaikan soal cerita pada materi keliling dan luas lingkaran. Populasi dalam penelitian ini adalah seluruh siswa kelas VIII SMP Negeri 1 Kota Ternate dan sampel yang secara acak di ambil yaitu siswa kelas VIII ${ }^{\mathrm{A}}$ sebagai kelas eksperimen yang berjumlah 27 siswa dan kelas VIII ${ }^{\mathrm{B}}$ sebagai kelas kontrol yang berjumlah 30 siswa. Pengumpulan data dilakukan melalui tes hasil belajar siswa dengan 5 butir soal sebagai instrumen yang telah divalidasi oleh validator. Analisis data yang digunakan adalah PAP skala 5, uji homogenitas, uji normalitas, uji the mann-whitney test dan uji hipotesis. Hasil perhitungan uji homogenitas tes awal diperoleh $\mathrm{F}_{\text {hitung }}=1,29$ kurang dari $\mathrm{F}_{\text {tabel }}=1,90$ maka kedua data homogen. Pada uji normalitas data tes akhir diperoleh $\chi^{2}$ hitung $>\chi^{2}$ tabel atau 9,90> 7,82 untuk kelas eksperimen dan $\chi^{2}$ hitung $>$ $\chi^{2}$ tabel atau 10,56>7,82 untuk kelas kontrol, artinya kedua data kelompok tidak berdistribusi normal, sehingga digunakan uji statistik non parametrik. Pengujian non parametrik yang digunakan adalah uji the mann-whitney test, dari hasil perhitungan diperoleh $Z_{\text {hitung }}=-4,14$ dengan $Z_{\text {tabel }}= \pm 1,96$ pada taraf signifikan $(\alpha)=0,05$, Terima $\mathrm{H}_{0}$ jika $-\mathrm{Zt} \leq \mathrm{Z}_{\mathrm{H}} \leq+\mathrm{Zt}$ dan Tolak $\mathrm{H}_{0}$ jika $\mathrm{Z}_{\mathrm{H}}>\mathrm{Zt}$ atau $\mathrm{Z}_{\mathrm{H}}<-\mathrm{Zt}$. Karena $\mathrm{Z}_{\mathrm{H}}$ $<\mathrm{Z}_{\mathrm{t}}(-4,14<-1,96)$, maka $\mathrm{H}_{0}$ di tolak dan $\mathrm{H}_{1}$ di terima artinya terdapat perbedaan hasil belajar siswa antara kelas eksperimen dan kelas kontrol pada siswa kelas VII SMP Negeri 1 Kota Ternate. Dengan demikian, terdapat perbedaan hasil belajar pada siswa kelas VIII SMP Negeri 1 Kota Ternate yang menggunakan model pembelajaran tutor sebaya dengan penggunaan LKS dan yang tidak menggunakan model pembelajaran tersebut. Berdasarkan mean, tingkat penguasaan yang diperoleh kelas eksperimen dan kelas kontrol, serta aktivitas dan respon siswa terhadap model pembelajaran tutor sebaya dengan penggunaan LKS, maka dapat disimpulkan bahwa penerapan model pembelajaran tutor sebaya dengan penggunaan LKS efektif untuk meningkatkan hasil belajar siswa dalam menyelesaikan soal cerita pada materi keliling dan luas lingkaran.
\end{abstract}

Kata Kunci: hasil belajar, lingkaran, lks, tutor sebaya

\section{EFFECTIVENESS OF THE TUTOR LEARNING MODEL USE OF LKS ON STUDENT LEARNING OUTCOMES IN COMPLETING STORAGE PROBLEMS IN THE CIRCLE AND CIRCULAR MATERIALS}

\begin{abstract}
This research is an experimental research which aims to determine the effectiveness of peer tutoring learning models with the use of LKS on student learning outcomes in solving the story problems in the material around and the area of the circle. The population in this study were all eighth grade students of
\end{abstract}


SMP Negeri 1 Kota Ternate and samples that were randomly taken were class VIIIA students as an experimental class which amounted to 27 students and class VIIIB as a control class totaling 30 students. Data collection is done through tests of student learning outcomes with 5 items as instruments that have been validated by the validator. The analysis of the data used is 5-scale PAP, homogeneity test, normality test, the Mann-Whitney test and hypothesis test. The results of the calculation of the initial homogeneity test obtained F count $=1.29$ less than Ftable $=1.90$, then the two data are homogeneous. In the normality test the final test data is obtained $\chi 2$ count $>$ tabel 2 tables or $9.90>7.82$ for the experimental class and $\chi 2$ count $>\chi 2$ tables or $10.56>7.82$ for the control class, meaning that the two group data are not normally distributed, so used non parametric statistical tests. The non parametric test used is the Mann-Whitney test, from the calculation results obtained by Zhitung $=-4.14$ with Ztable $= \pm 1.96$ at a significant level () $=0.05$, Accept $\mathrm{H} 0$ if $-\mathrm{Zt} \leq \mathrm{ZH} \leq+\mathrm{Zt}$ and Reject $\mathrm{H} 0$ if $\mathrm{ZH}>\mathrm{Zt}$ or $\mathrm{ZH}<-\mathrm{Zt}$. Because $\mathrm{ZH}<\mathrm{Zt}(-4.14<-$ 1,96), then $\mathrm{H} 0$ is rejected and $\mathrm{H} 1$ is accepted, meaning that there are differences in student learning outcomes between the experimental class and the control class in class VII students of SMP Negeri 1 Ternate City. Thus, there are differences in learning outcomes in class VIII students of SMP Negeri 1 Kota Ternate who use peer tutoring learning models with the use of LKS and those who do not use the learning model. Based on the mean, level of mastery obtained by the experimental class and the control class, as well as student activities and responses to peer tutoring learning models with the use of LKS, it can be concluded that the application of peer tutoring learning models with the use of effective LKS to improve student learning outcomes material around and area of circle.

Keywords: Learning Outcomes, Circles, LKS, Peer Tutors

\section{Pendahuluan}

Kehidupan sehari-hari selalu terkait dengan berbagai permasalahan dan setiap permasalahan tentu memerlukan suatu pemecahan atau penyelesaian. Ada masalah-masalah dalam kehidupan sehari-hari yang tidak dapat diselesaikan dengan menggunakan matematika. Tetapi tidak sedikit pula masalah yang dapat diselesaikan dengan menggunakan matematika. Masalah-masalah yang berkaitan erat dengan berbagai aspek kehidupan sehari-hari di masyarakat mengindikasikan bahwa penguasaan dan pemahaman pelajaran matematika yang berkaitan erat dengan kehidupan di masyarakat sangatlah penting. Misalnya masalah dalam dunia perdagangan yang mencakup jumlah, selisih, rugi laba, potongan harga, dan bunga. Masalahmasalah pengukuran seperti jarak, waktu, keliling, luas, volume, kecepatan, dan lain-lain.

Agar kelak siswa mampu menghadapi dan menyelesaikan permasalahan yang berkaitan erat dengan berbagai aspek dalam kehidupan seharihari maka sejak dini perlu diberi bekal yang cukup melalui pendidikan di sekolah-sekolah. Namun kenyataan yang ada sangat sulit mengarahkan siswa dalam memecahkan suatu masalah yang berkaitan dengan matematika. Berdasarkan hasil diskusi dengan guru matematika di Sekolah Menengah Pertama (SMP) Negeri 1 Kota Ternate, ternyata sebagian besar siswa mengalami kesulitan dalam menyelesaikan soal matematika khususnya soal cerita sehingga hasilnya kurang memuaskan. Salah satu contohnya pada materi keliling dan luas lingkaran, dimana hampir seluruh siswa mendapat kesulitan dalam menyelesaikan soal latihan yang berbentuk soal cerita, setelah didiskusikan lebih lanjut ternyata di dalam mengikuti materi tersebut mereka mendapat banyak kesulitan dalam membaca maksud soal, mengubahnya dalam bentuk matematika dan sebagainya.

Kesulitan yang dialami siswa tersebut diakibatkan pada model pembelajaran yang kurang tepat dan kurangnya kemampuan komunikasi matematika yang bisa mempengaruhi hasil belajar siswa. Oleh karena itu perlu diupayakan suatu pembelajaran yang dapat meningkatkan kemampuan siswa dalam menyelesaikan soal cerita matematika. Salah satu model pembelajaran yang dapat menjawab permasalahan tersebut adalah model pembelajaran tutor sebaya. Menurut Zaini (Suyitno, 2005:34) model pembelajaran yang paling baik adalah dengan mengajarkan kepada orang lain. Oleh karena itu, pemilihan model pembelajaran tutor sebaya sebagai strategi pembelajaran akan sangat membantu siswa dalam mengajarkan materi kepada teman-temannya.

Pemilihan model pembelajaran tutor sebaya dirasa tepat karena materi keliling dan luas lingkaran yang berkaitan dengan soal cerita menuntut siswa untuk lebih memahami matematika dalam bentuk verbal, sehingga ketika 
teman sebaya yang menerangkan diharapkan penyampaian kalimat matematika lebih mudah dipahami. Selain alasan tersebut, pemilihan model pembelajaran tutor sebaya dikarenakan di SMP Negeri 1 Kota Ternate model pembelajaran tutor sebaya belum pernah diterapkan dalam proses pembelajaran matematika.

Selain model pembelajaran guru perlu juga memperhatikan penggunaan media pembelajaran, yang tepat dan mendukung isi bahan pelajaran sehingga akan sangat membantu siswa dalam memahami materi atau konsep yang diajarkan oleh guru (Djamarah dan Zain, 2010:132). Salah satu media yang dapat digunakan untuk mendukung proses pembelajaran adalah media Lembar Kerja Siswa (LKS).

LKS merupakan salah satu sumber belajar dan media pembelajaran yang dirasa dapat membantu siswa maupun guru dalam proses pembelajaran. LKS merupakan jenis hand out yang dimaksudkan untuk membantu siswa belajar secara terarah. Keberadaan LKS memberi pengaruh yang cukup besar dalam proses belajar mengajar (Rohaeti dkk, 2011:11).

\subsection{Rumusan Masalah}

1.1.1 Bagaimana hasil belajar siswa kelas VIII SMP Negeri 1 Kota Ternate dalam menyelesaikan soal cerita pada materi keliling dan luas lingkaran yang diajarkan dengan menggunakan model pembelajaran tutor sebaya dengan penggunaan LKS?

1.1.2 Apakah model pembelajaran tutor sebaya dengan penggunaan LKS efektif dalam mengajarkan materi keliling dan luas lingkaran yang berkaitan dengan soal cerita?

\subsection{Tujuan Penelitian}

1.2.1 Untuk mengetahui hasil belajar siswa kelas VIII SMP Negeri 1 Kota Ternate dalam menyelesaikan soal cerita pada materi keliling dan luas lingkaran yang diajarkan dengan menggunakan model pembelajaran tutor sebaya dengan penggunaan LKS.

1.2.2 Untuk mengetahui efektivitas model pembelajaran tutor sebaya dengan penggunaan LKS dalam mengajarkan materi keliling dan luas lingkaran yang berkaitan dengan soal cerita.

\section{Metode Penelitian}

\subsection{Jenis Penelitian}

Tipe penelitian yang digunakan adalah penelitian eksperimen (Eksperimen Research). Penelitian eksperimen adalah penelitian dimana variabel yang hendak diteliti kehadirannya sengaja ditimbulkan dengan memanipulasi menggunakan perlakuan (Purwanto, 2007:180).

Bentuk desain eksperimen yang digunakan adalah true experimental design. Ciri utama dari true experimental adalah bahwa, sampel yang digunakan untuk eksperimen maupun sebagai kelompok kontrol diambil secara random dari populasi tertentu (Sugiyono, 2010:75-76).

\subsection{Populasi dan Sampel Penelitian}

Populasi adalah wilayah generalisasi yang terdiri atas obyek/subyek yang mempunyai kuantitas dan karakteristik tertentu yang ditetapkan oleh peneliti untuk dipelajari dan kemudian ditarik kesimpulannya (Sugiyono, 2010:80). Populasi penelitian ini adalah seluruh siswa kelas VIII SMP Negeri 1 Kota Ternate yang berjumlah 457 siswa dan tersebar dari kelas VIII ${ }^{\mathrm{A}}$ sampai VIII ${ }^{\mathrm{O}}$.

Sampel adalah sebagian dari jumlah dan karakteristik yang dimiliki oleh populasi (Sugiyono, 2010:80) Sampel dari penelitian ini adalah kelas $\mathrm{VIII}^{\mathrm{A}}$ yang berjumlah 27 siswa dan kelas VIII ${ }^{\mathrm{B}}$ yang berjumlah 30 siswa. Teknik pengambilan sampel dilakukan secara cluster random sampling artinya teknik sampling yang memberikan peluang yang sama bagi anggota populasi untuk dipilih menjadi anggota sampel tanpa memperhatikan strata yang ada dalam populasi itu (Sugiyono, 2010:83).

\subsection{Variabel Penelitian}

Variabel dalam penelitian ini merupakan variabel tunggal, yaitu hasil belajar siswa dalam menyelesaikan soal cerita pada keliling dan luas lingkaran yang dilambangkan dengan $x$. Variabel $x$ diperinci atas $x_{1}$ dan $x_{2}$, dimana $x_{1}$ adalah hasil belajar siswa dalam menyelesaikan soal cerita pada keliling dan luas lingkaran yang diajarkan dengan model pembelajaran tutor sebaya dengan penggunaan LKS dan $x_{2}$ adalah hasil belajar siswa dalam menyelesaikan soal cerita pada keliling dan luas lingkaran yang tidak diajarkan 
dengan model pembelajaran tutor sebaya dengan penggunaan LKS.

\subsection{Prosedur Penelitian}

Secara ringkas, tahapan alur penelitian yang dilakukan digambarkan sebagai berikut:

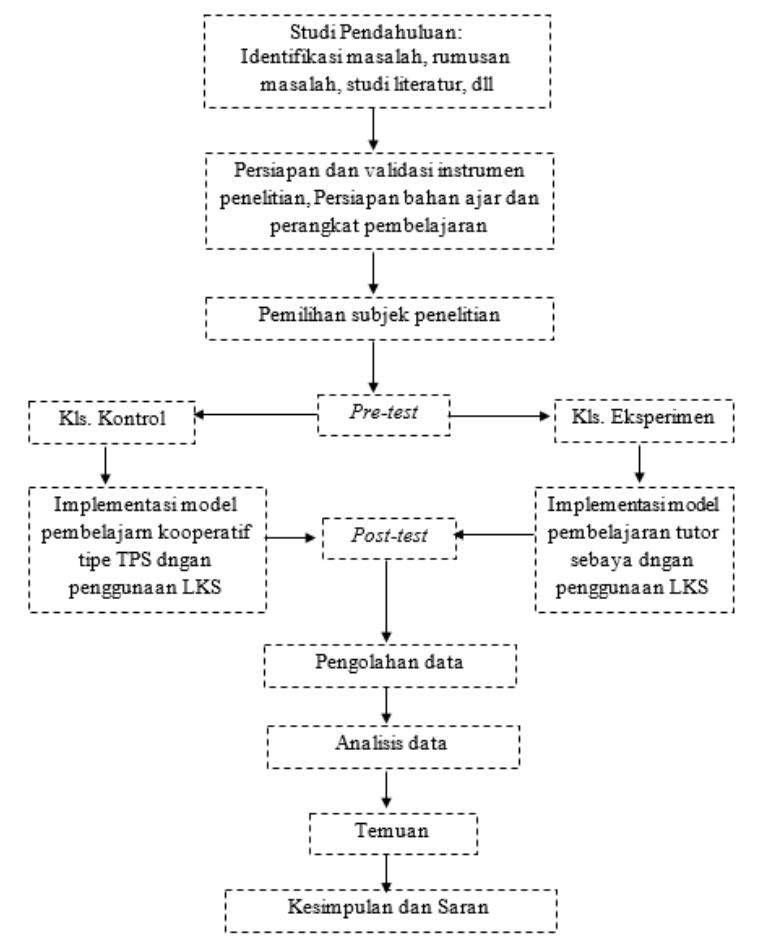

Gambar 1. Tahapan alur penelitian

\subsection{Teknik Pengumpulan Data}

\subsubsection{Teknik Tes}

Teknik tes yang digunakan terdiri dari tes awal (pree-test) dan tes akhir (post-test) yang bertujuan untuk mengetahui hasil belajar siswa sebelum dan sesudah diterapkan model pembelajaran. Selain itu hasil tersebut selanjutnya digunakan sebagai data dalam uji statistik.

\subsubsection{Lembar Observasi}

Lembar observasi digunakan untuk memperoleh data pengelolaan pembelajaran tutor sebaya dengan penggunaan LKS oleh guru dan aktivitas siswa selama pembelajaran. Lembar observasi ini disediakan oleh peneliti yang diisi oleh guru mata pelajaran selaku observer.

2.5.3. Wawancara

Wawancara digunakan untuk mengetahui kendala siswa dalam menyelesaikan soal cerita pada materi keliling dan luas lingkaran serta respon siswa terhadap model pembelajaran tutor sebaya dengan penggunaan LKS.

\subsection{Instrumen Penelitian}

Instrumen dalam penelitian terdiri dari instrumen tes dan non tes. Instrumen penelitian tes berupa soal-soal yang disusun berdasarkan tujuan dan indikator materi keliling dan luas lingkaran. Soal tes dimaksud berbentuk essay yang berjumlah 5 butir soal. Soal disusun oleh peneliti dengan memperhatikan kompetensi dasar dan indikator serta divalidasi menurut validasi isi oleh dosen pembimbing dan guru mata pelajaran. Sedangkan instrumen penelitian non tes terdiri dari lembar observasi dan lembar pedoman wawancara.

\subsection{Teknik Analisis Data}

Sebelum data dianalisis lebih lanjut, terlebih dahulu dihitung presentase tingkat penguasaan siswa dari skor yang dicapai oleh setiap siswa pada tes awal. Rumus TP yang digunakan adalah :

Keterangan :

$$
\mathrm{TP}=\frac{m}{n} \times 100 \%
$$

TP : Tingkat Penguasaan

$\mathrm{m}$ : skor yang diperoleh

$\mathrm{n}$ : skor total

Untuk mengetahui kualifikasi penguasaan siswa disesuaikan dengan kriteria penilaian acuan patokan (PAP) skala 5, selanjutnya uji yang dilakukan adalah uji homogenitas dan uji normalitas data. Dari hasil uji normalitas data, diperoleh bahwa data tidak berdistribusi normal, maka statistik uji yang digunakan adalah statistik uji non parametrik yaitu uji U Test (The MannWhitney Test), dengan langkah-langkah sebagai berikut :

1) Memberikan rangking tertentu untuk setiap nilai yang dicapai. Dengan mengasumsikan bahwa rangking 1 adalah untuk nilai yang paling rendah, rangking ke-2 untuk nilai yang lebih tinggi dan seterusnya hingga rangking yang paling tinggi dicapai.

2) Menjumlahkan nilai rangking yang diperoleh pada setiap grup atau daerah, yaitu $\mathrm{R}_{1}$ untuk grup 1 dan $\mathrm{R}_{2}$ untuk grup 2 .

3) Untuk uji statistik U, kemudian dihitung : dari sampel pertama dengan $n_{1}$ pengamatan

\section{$\mathrm{R} 1$}

$$
\mathrm{U}=\mathrm{n} 1(\mathrm{n} 2)+\frac{\mathrm{n}_{1}\left(\mathrm{n}_{1}+1\right)}{2}-
$$

Atau dari sampel kedua dengan $n_{2}$ pengamatan

$$
\mathrm{R} 2
$$

$$
\mathrm{U}=\mathrm{n} 1(\mathrm{n} 2)+\frac{n_{2}\left(n_{2}+1\right)}{2}-
$$

4) Mencari nilai harapan (expected value) mean dan standar deviasi.

$$
\text { Mean }=\mathrm{E}(\mathrm{U})=\frac{n_{1} n_{2}}{2}
$$




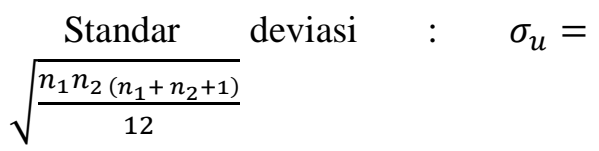

5) Dilakukan uji statistik:

$$
\mathrm{Z}=\frac{\mathrm{U}-\mathrm{E}(\mathrm{U})}{\sigma_{\mathrm{U}}}
$$

6) Kriteria pengujian :

i. Terima $\mathrm{H}_{0}$ jika $-\mathrm{Zt} \leq \mathrm{Z}_{\mathrm{H}} \leq+\mathrm{Zt}$

ii. Tolak $\mathrm{H}_{0}$ jika $\mathrm{Z}_{\mathrm{H}}>\mathrm{Zt}$ atau $\mathrm{Z}_{\mathrm{H}}<-\mathrm{Zt}$

7) Kesimpulan:

$\mathrm{H}_{0}$ : Tidak terdapat perbedaan

$\mathrm{H}_{1}$ : Adanya perbedaan

Saleh (2010:15-16).

\section{Hasil dan Pembahasan}

\subsection{Hasil Penelitian}

Data hasil penelitian ini diperoleh melalui tes tertulis dari 27 siswa kelas VIII ${ }^{\mathrm{A}}$ dan 30 siswa kelas VIII ${ }^{\mathrm{B}}$ SMP Negeri 1 Kota Ternate. Sebelum melakukan kegiatan belajar mengajar dengan model pembelajaran tutor sebaya dengan penggunaan LKS, peneliti mengadakan tes awal yang diikuti siswa kelas VIII ${ }^{\mathrm{A}}$ dan VIII ${ }^{\mathrm{B}}$. Hasil tes awal menunjukan bahwa lebih dari $80 \%$ nilai siswa masih berada dalam kategori gagal. Hasil tersebut kemudian dijadikan acuan untuk membagi kelas eksperimen dan kelas kontrol, dimana kelas eksperimen merupakan kelas yang memperoleh nilai rata-rata 30,3 (kelas VIII ${ }^{\mathrm{A}}$ ) dan kelas kontrol yaitu kelas yang memperoleh nilai rata-rata 32,7 (kelas $\mathrm{VIII}^{\mathrm{B}}$ ), tetapi dari hasil uji homogenitas data nilai kedua kelas tersebut adalah homogen.

Pembelajaran dilakukan selama 2 minggu dan setelah pembelajaran dilakukan pada dua kelas dimaksud, peneliti memberikan tes akhir kepada siswa. Hal ini dimaksudkan untuk mengukur tingkat penguasaan siswa dalam menyelesaikan soal cerita pada materi keliling dan luas lingkaran yang sudah diberikan. Berdasarkan hasil tes tersebut rata-rata hasil belajar siswa pada kelas eksperimen dan kelas kontrol adalah 78,5 dan 56,37. Nilai rata-rata yang diperoleh menunjukan bahwa tingkat penguasaan siswa dalam menyelesaikan soal cerita pada materi keliling dan luas lingkaran mencapai 78,5 \% pada kelas eksperimen dan 56,37 \% pada kelas kontrol. Jika dilihat pada tes awal dan tes akhir maka terjadi peningkatan tingkat penguasaan siswa setelah model pembelajaran dengan penggunaan LKS digunakan pada kelas eksperimen dan metode konvensional pada kelas kontrol dalam menyelesaikan soal cerita pada materi keliling dan luas lingkaran.

Hasil belajar siswa pada kelas eksperimen setelah dikonversi ke PAP skala 5 terdapat 6 siswa $(22,2 \%)$ kualifikasi memuaskan,10 siswa
(37\%) kualifikasi baik, 3 siswa (11,1\%) kualifikasi cukup, 2 siswa $(7,4 \%)$ kualifikasi kurang dan 6 siswa $(22,2 \%)$ kualifikasi gagal. Sedangkan pada kelas kontrol tidak terdapat siswa dalam kualifikasi memuaskan, 3 siswa (10\%) kualifikasi baik, 4 siswa $(13,3 \%)$ kualifikasi cukup, 4 siswa $(13,3 \%)$ kualifikasi kurang dan 19 siswa $(63,3 \%)$ berkualifikasi gagal.

Selanjutnya analisis data hasil belajar siswa di awali dengan melakukan uji normalitas data untuk siswa kelas kontrol dengan chikuadrat. Uji normalitas dilakukan dengan melihat apakah data berdistribusi normal atau tidak, dan selanjutnya untuk menentukan statistik uji yang akan digunakan untuk menguji hipotesis.

Hasil uji chi-kuadrat menunjukan data tidak berdistribusi normal yaitu:

3.1.1. Hasil uji normalitas data untuk siswa kelas eksperimen dengan rumus chikuadarat diperoleh nilai $\chi^{2}$ hitung $=9,86$ dan $\chi_{\text {tabel }}^{2}=7,82(\alpha=5 \%, \mathrm{dk}=3)$, karena $\chi^{2}$ hitun $>\chi^{2}$ tabel maka kesimpulan data tidak berdistribusi normal.

3.1.2. Hasil uji normalitas data untuk siswa kelas kontrol dengan rumus chi-kuadrat diperoleh nilai $\chi^{2}$ hitung $=10,56$ dan $\chi^{2}$ tabel $=7,82(\alpha=5 \%, \mathrm{dk}=3)$, karena $\chi^{2}$ hitung $>$ $\chi^{2}$ tabel maka kesimpulannya data tidak berdistribusi normal.

Sehingga statistik uji yang digunakan adalah statistik uji non parametrik yakni uji the mann-whitney test. Hasil uji the mann-whitney test untuk mengetahui perbedaan hasil belajar siswa antara kelas kontrol dan eksperimen (lampiran 26 halaman 95) diperoleh $\mathrm{Z}_{\text {hitung }}=-4,14$ dengan $\mathrm{Z}_{\text {tabel }}=$ $\pm 1,96$ pada taraf signifikan $\quad(\alpha=0,05)$ terima $\mathrm{H}_{0}$ jika $-1,96 \leq \mathrm{Z}_{\mathrm{H}} \leq+1,96$ dan tolak $\mathrm{H}_{0}$ jika $\mathrm{Z}_{\mathrm{H}}>$ 1,96 atau $\mathrm{Z}_{\mathrm{H}}<-1,96$. Karena $\mathrm{Z}_{\mathrm{H}}<\mathrm{Z}_{\mathrm{t}}(-4,14<-$ 1,96), maka $\mathrm{H}_{0}$ di tolak dan $\mathrm{H}_{1}$ di terima artinya terdapat perbedaan hasil belajar siswa antara kelas eksperimen dan kelas kontrol pada siswa kelas VII SMP Negeri 1 Kota Ternate.

Data hasil observasi oleh guru mata pelajaran menunjukan kemampuan peneliti terhadap pengelolaan kelas adalah $79 \%$ dan aktivitas siswa mencapai $81 \%$. Selain itu dari hasil wawancarsa yang dilakukan kepada 6 siswa diperoleh bahwa rata-rata mengalami kendala dalam menyelesaikan soal nomor 4 dan soal nomor 5 karena masalah perhitungan. Seluruh siswa yang diwawancarai juga memberikan respon yang positif terhadap model pembelajaran tutor sebaya dengan penggunaan LKS.

\subsection{Pembahasan}


Berdasarkan hasil analisis data dari 30 siswa pada kelas kontrol didapati skor yang diperoleh berkisar antara 33 sampai 90 . Hal ini menunjukan bahwa siswa belum bisa menyelesaikan soal dengan baik, sedangkan skor yang diperoleh 27 siswa pada kelas eksperimen berkisar antara 41 sampai 100, yang berarti bahwa siswa yang diajarkan dengan model pembelajaran tutor sebaya dengan penggunaan LKS dapat menyelesaikan soal dengan baik.

Hasil belajar siswa tes akhir pada kelas eksperimen dan kelas kontrol dapat dijabarkan sebagai berikut :

3.2.1. Pada kelas eksperimen terdapat 6 siswa atau $22,2 \%$ berkualifikasi gagal, dimana diantara keenam siswa tersebut 1 siswa tidak dapat mengerjakan 3 nomor soal terakhir, 1 siswa salah dalam menyelesaikan soal nomor 4 yaitu dalam menentukan hasil akhir dalam mencari jari-jari lingkaran dan tidak dapat menyelesaikan soal nomor 3 dan soal nomor 5, dan 4 siswa tidak dapat mengerjakan soal nomor 4 dan soal nomor 5. Sedangkan, pada kelas kontrol terdapat 19 siswa atau 63,3\% berkualifikasi gagal, dimana 4 siswa tidak dapat mengerjakan 3 soal terakhir, 1 siswa salah dalam menyelesaikan soal nomor 3 dan 5 tentang luas lingkaran serta tidak dapat mengerjakan soal nomor 2, 11 siswa keliru dalam menentukan hasil akhir soal no 4 dan 5 yakni dalam menentukan jari-jari lingkaran yang luas atau kelilingnya diketahui serta tidak dapat menyelesaikan soal nomor 5, dan 3 siswa keliru dalam menentukan luas lingkaran pada soal nomor 5 serta tidak dapat menyelesaikan soal nomor 3 dan soal nomor 4.

3.2.2. 2 siswa atau $7,4 \%$ berkualifikasi kurang untuk kelas eksperimen dan 4 siswa atau 13,3 \% untuk kelas kontrol. Pada kelas eksperimen kedua siswa tersebut mengalami kesalahan dalam menentukan jawaban akhir soal nomor 4 yakni jari-jari lingkaran serta tidak menyelesaikan soal nomor 5. Sedangkan pada kelas kontrol 3 siswa keliru dalam menentukan jari-jari lingkaran yang luas atau kelilingnya diketahui yang terdapat pada soal nomor 3 dan 5, dan 1 siswa tidak dapat mengerjakan soal nomor 3 serta tidak memberikan salah satu jawaban akhir pada soal nomor 1 .

3.2.3. 3 siswa atau $11,1 \%$ berkualifikasi cukup pada kelas eksperimen dan 4 siswa atau 13,3 \% berkualifikasi cukup pada kelas kontrol. Pada kelas eksperimen 2 siswa diantaranya salah menentukan jawaban akhir soal nomor 1 serta tidak menyelesaikan soal nomor 5 tentang luas lingkaran, dan satu siswa lainnya salah dalam menentukan jawaban akhir soal nomor 3 tentang jari-jari lingkaran serta salah dalam mengkalkulasi jawaban akhir soal nomor 5. Pada kelas kontrol, 2 siswa tidak menyelesaikan soal nomor 3 dan 4 , 1 siswa salah menggunakan rumus untuk pemecahan masalah pada keliling lingkaran serta keliru dalam menafsirkan soal nomor 2, dan 1 siswa lainnya tidak dapat menyelesaikan soal nomor 3 dalam menentukan jari-jari lingkaran yang luasnya diketahui.

3.2.4. 10 siswa atau $37 \%$ berkualifikasi baik pada kelas eksperimen, dalam hal ini siswa telah memahami materi yang telah diajarkan hanya saja 1 siswa keliru dalam menghitung keliling lingkaran pada jawaban akhir soal nomor 1 serta salah dalam menentukan luas lingkaran pada soal nomor 5, 2 siswa tidak dapat mengerjakan soal nomor 5 tentang luas lingkaran, 1 siswa keliru dalam menentukan keliling dan luas lingkaran pada jawaban akhir soal nomor 1 serta salah dalam menentukan jawaban akhir soal nomor 4 dalam menentukan jari-jari lingkaran. 3 siswa keliru dalam menentukan jawaban akhir soal nomor 3 , 4, serta soal nomor 5, dan 3 siswa keliru dalam menyelesaikan soal nomor 5 . Sedangkan pada kelas kontrol terdapat 3 siswa atau $10 \%$ berkualifikasi baik, karena ketiga-tiganya sudah memahami materi yang diajarkan hanya saja 2 siswa masih mengalami kekeliruan dalam menafsirkan maksud soal nomor 2 dan 4 tentang keliling lingkaran sehingga salah dalam menentukan jawaban akhir, dan 1 siswa keliru dalam mengkalkulasi jawaban akhir soal nomor 2 .

3.2.5. 6 siswa atau $22,2 \%$ berkualifikasi memuaskan pada kelas eksperimen, dimana 4 siswa sedikit keliru dalam menentukan jawaban akhir soal nomor 2 , 3 dan 5, dan 2 siswa lainnya tidak 
mengalami permasalahan di setiap nomor soal dan memperoleh nilai sempurna. Sedangkan pada kelas kontrol tidak terdapat siswa pada kualifikasi memuaskan, hal ini berarti pemahaman atau tingkat penguasaan siswa pada kelas kontrol belum ada yang mencapai $91 \%$.

Dengan demikian hasil penelitian menunjukan bahwa hasil belajar siswa pada kelas eksperimen lebih baik dibandigkan hasil belajar siswa pada kelas kontrol.

Berdasarkan hasil observasi selama penerapan model pembelajaran tutor sebaya dengan penggunaan LKS diperoleh kemampuan guru terhadap pengelolaan kelas mencapai $79 \%$ dan aktivitas siswa mencapai $81 \%$. Hal ini menunjukkan bahwa suasana kelas tersebut aktif dan kondusif. Sebagian besar siswa mengikuti proses pembelajaran dengan baik, seperti melakukan aktivitas matematis, melakukan diskusi dengan baik, saling menghargai pendapat masing-masing, dan melakukan presentasi dengan jelas.

Selain itu dari hasil proses wawancara menunjukkan bahwa sebagian besar siswa tidak mengalami kendala dalam menyelesaikan soal cerita pada materi keliling dan luas lingkaran, hanya saja salah dalam perhitungan dan mengalami sedikit kesalahan interpretasi terhadap apa yang diketahui dalam soal. Secara keseluruhan siswa juga menyukai pembelajaran matematika yang dilakukan oleh guru mata pelajaran mereka selama ini serta menerima dengan baik dan menyatakan senang atas penerapan model pembelajaran tutor sebaya dengan penggunaan LKS.

\section{Kesimpulan}

Berdasarkan hasil penelitian dan hasil analisis data yang diperoleh dari sampel yang berjumlah 27 siswa kelas VIII ${ }^{\mathrm{A}}$ dan 30 siswa kelas VIII $^{B}$ SMP Negeri 1 kota Ternate sebagai kelas eksperimen dan kelas kontrol dapat disimpulkan beberapa hal-hal sebagai berikut:

4.1 Hasil belajar siswa kelas eksperimen lebih tinggi daripada hasil belajar kelas kontrol, hal ini ditunjukan oleh hasil interpretasi tingkat penguasaan, dimana kelas eksperimen yang diterapakan dengan model pembelajaran tutor sebaya dengan penggunaan LKS memperoleh $78,4 \%$ dan sedangkan siswa yang menggunakan model pembelajaran kooperatif tipe TPS hanya mencapai $56,37 \%$.
4.2 Berdasarkan hasil analisis data dengan uji the mann-whitney test menunjukkan terdapat perbedaan hasil belajar siswa antara kelas eksperimen dan kelas kontrol pada siswa kelas VII SMP Negeri 1 Kota Ternate. Dengan demikian, terdapat perbedaan antara hasil belajar pada siswa kelas VIII SMP Negeri 1 Kota Ternate yang diterapkan model pembelajaran tutor sebaya dengan penggunaan LKS dan yang tidak diterapkan model pembelajaran tersebut. Selain itu berdasarkan mean atau tingkat penguasaan yang diperoleh dan aktivitas siswa selama proses kegiatan belajar mengajar yang diterapkan model pembelajaran tutor sebaya dengan penggunaan LKS, dapat disimpulkan bahwa penerapan model pembelajaran tutor sebaya dengan penggunaan LKS efektif terhadap hasil belajar siswa dalam menyelesaikan soal cerita pada materi keliling dan luas lingkaran.

\section{Daftar Pustaka}

Djamarah, S.B. dan Zain, A. (2010). Strategi Belajar Mengajar. Jakarta: Rineka Cipta.

Purwanto. (2007). Metodologi Penelitian Kuantitatif untuk Psikologi dan Pendidikan. Yogyakarta: Pustaka Pelajar.

Rohaeti, E., LFX, E.W. dan Padmaningrum, R.T. (2011). Pengembangan Lembar Kerja Siswa (LKS). Diakses pada tanggal 1 Januari 2013, dari http://staff.uny.ac.id.

Saleh, Samsubar.(2010). Statistik Nonparametrik Edisi 2. Yogyakarta: BPFE.

Sugiyono. 2010. Metode Penelitian Pendidikan. Bandung: Alfabeta.

Suyitno, Amin. 2005. Dasar-Dasar dan Proses Pembelajaran Matematika 1. Semarang: FMIPA Universitas Negeri Semarang. 
